\title{
Antidiabetic Activity of Administration of Aqueous Extract of Berberis holstii
}

\author{
Njeri L Kimani ${ }^{1 *}$, Njangiru IK ${ }^{2}$, Eliud NM Njagi ${ }^{1}$ and George O Orinda ${ }^{1}$ \\ ${ }^{1}$ Department of Biochemistry and Biotechnology, School of Pure and Applied Sciences, Kenyatta University, P.O. Box 43844-00100, Nairobi, Kenya \\ ${ }^{2}$ Department of chemistry and Biochemistry, Laikipia University, P.O Box 1100-20300 Nyahururu, Kenya
}

"Corresponding author: Njeri L Kimani, Department of Biochemistry and Biotechnology, School of Pure and Applied Sciences, Kenyatta University, P.O. Box 43844-00100, Nairobi, Kenya, Tel: +254723688287; E-mail: lucy3kimani@yahoo.com

Received date: November 03, 2017; Accepted date: November 20, 2017; Published date: November 25, 2017

Copyright: (c) 2017 Kimani NL, et al. This is an open-access article distributed under the terms of the Creative Commons Attribution License, which permits unrestricted use, distribution, and reproduction in any medium, provided the original author and source are credited.

\begin{abstract}
Diabetes mellitus in Kenya is of public health concern since it causes significant mortality and complications that are long term. Though conventional drugs are used in the management of diabetes mellitus they are expensive, unavailable and also have numerous side effects. Berberis are medicinally important and are used for various purposes. Berberis holstii has traditionally been used in the management of diabetes; however, the efficacy of this herb needs to be evaluated scientifically.

The study aimed at determining the in vivo antidiabetic effects of root extracts of Berberis holstii in alloxaninduced diabetic male mice. In this study, eight groups of animals with five mice each were used. The reductions in blood glucose relative to their initial values were determined after oral and intraperitoneal administration of $25,48.4$, $93.5,180.9$, and $350 \mathrm{mg} / \mathrm{kg}$ body weight. Standard hypoglycemic used to compare results were $200 \mathrm{mg} / \mathrm{kg}$ body weight $(4.6 \mathrm{mg}$ of glibenclamide) for oral route and $1 \mathrm{IU} / \mathrm{kg}$ body weight dose of insulin for an intraperitoneal route. The levels of glucose were measured at the start of the experiment and repeated at intervals of 2 hours up to 10 hours and at 24 hours after administering the drug. Significant $(\rho<0.05)$ reduction in blood sugar relative to their initial values was determined for all treated diabetic groups at the end of the experiment. The composition of phytochemicals was determined using standard procedures. The results were analyzed using ANOVA and postANOVA.
\end{abstract}

The results showed that the plant extract at $25,48.4,93.5,180.9$, and $350 \mathrm{mg} / \mathrm{kg}$ body weight administered effectively reduced blood glucose levels (up to $30 \%$ reduction) which could be associated with the phytochemicals present which possesses antidiabetic activities. The extracts contained tannins, flavonoids, saponins, phenols and alkaloids. The study, therefore, recommends the use of Berberis holstii in the management of diabetes mellitus.

Keywords: Hypoglycemic; Berberis holstii; Antidiabetic activity; IU (Insulin units); Diabetes mellitus; in vivo; Phytochemicals; Glibenclamide

Abbreviations: IU: Insulin units; SD: Standard deviation; SPSS: Statistical package of social sciences; ANOVA: Analysis of variance

\section{Introduction}

Diabetes mellitus is a disorder that alters the metabolism of carbohydrates, fats, and proteins. The disorder results from the shortage of insulin or lack of it or reduced sensitivity of the tissue to insulin [1]. About $25 \%$ of the World's population according to a survey is reported to have Diabetes Mellitus (DM). The prevalence of diabetes for all age groups worldwide is on the increase and has been projected as the World's main disabler and killer in the next 25 years [2]. Diabetes has several causes such as autoimmune destruction of pancreatic $\beta$-cell leading to deficiency in insulin (Type I) and other abnormalities that include genetic factors related to impaired insulin secretion, insulin resistance and environmental factors such as obesity, lack of exercise and stress, as well as aging (Type II) [3].
Diabetes mellitus is characterized by the production of large amounts of urine (polyuria), thirst (polydipsia), hunger (polyphagia), loss of weight, changes of vision and fatigue [4]. Chronic hyperglycemia results in long-term complications which are microvascular or macrovascular. These complications are retinopathy; nephropathy; peripheral neuropathy and autonomic neuropathy [5].

The ranges of normal fasting plasma sugar levels are between 3.5-6.7 $\mathrm{mmol} / \mathrm{l}(63-120.6 \mathrm{mg} / \mathrm{dl})$. Repeated fasting blood glucose levels $\geq 7.0$ $\mathrm{mmol} / \mathrm{L}(126 \mathrm{mg} / \mathrm{dl})$ or 2 -hour postprandial glucose values $\geq 11.1$ $\mathrm{mmol} / \mathrm{L}(200 \mathrm{mg} / \mathrm{L})$ is considered to be diagnostic criteria for diabetes [6].

The conventional drugs used in the management of diabetes mellitus have been expensive, unavailable and have been associated with numerous side effects [7]. The numerous side effects associated with conventional drugs used in management of diabetes mellitus leads to a growing interest in the herbal sources [8]. Diabetes mellitus patients are increasingly demanding for natural products and other dietary modulators with antihperglycemic effect. Management of diabetes can be by use of nutraceutical"products (food or part of food that prevent or treat a disease). Food provides protection because they contain beneficial phytochemicals which decreases the incidences and evolution of diabetes and metabolic syndrome [9]. Plants have been 
shown to contain a host of bioactive compounds which makes them a source for different types of drugs [10].

Plants have been found to have antidiabetic activity [11]. Some of these plants are proven to alleviate the symptoms and help in the prevention of the development of complications of the disease. Others help in the regeneration of $\beta$-cells hence overcoming resistance to insulin [12]. Example Ginkgo biloba extract has been shown to prevent and treat diabetic neuropathy at early-stage [10]. Berberis holstii has been in use by herbalists in the management of diabetes. These herbs are relatively inexpensive, available and have minimal side effects. However, only a few of these plants have received the scientific evaluation to determine their efficacy [11]. There is limited scientific evidence regarding the efficacy profiles to support the continued folkloric usage of Berberis holstii. This development is therefore crucial because it provides scientific evidence of the plant effectiveness in treating diabetes mellitus.

\section{Material and Methods}

\section{Collection of plant and preparation of extracts}

Roots of Berberis holstii were collected from their habitat. The collection was done under guidance from local herbalists on the antidiabetic activity of $B$. holstii. The plants were identified at the herbarium of the National Museum of Kenya.

Collected plant materials were cut into small pieces. The pieces were dried under shade to a constant dry weight. The dried materials were then powdered using an electric mill. A hundred grams of powder were extracted in 1 litre of double distilled water at $60^{\circ} \mathrm{C}$ in a metabolic shaker for 6 hours. The hot mixture was left to cool, followed by decantation into a dry conical flask over folded cotton gauze stuffed into a funnel. Freeze drying was done in $200 \mathrm{ml}$ portions of the filtrate for 48 hours. The freeze-dried sample was weighed and stored in airtight bottle at $-20^{\circ} \mathrm{C}$ until required for analysis.

\section{Experimental animals and induction of diabetes}

White male albino mice (three to four weeks old) weighing 22-27 g were considered in the study. Rodent pellets and water was used to feed the mice. Prior to the induction of diabetic state, the animals were fasted for about eight to twelve hours but allowed to access water. Intraperitoneal administration of 186.9 milligrams per kilogram body weight of 10 percent alloxan monohydrate was used to induce diabetic state. Control cohort was administered with normal saline through intraperitoneal route. 2 days post-induction of hyperglycemia, blood glucose was measured using a glucometer. Mice with blood glucose level above $2000 \mathrm{mg} / \mathrm{L}(>11.1 \mathrm{mmol} / \mathrm{L})$ were considered diabetic and were included for subsequent treatment.

\section{Experimental design}

In the experiment, the mice were divided into eight groups of five mice each. This was done for oral and intraperitoneal routes of drug administration. Group I mice (Normal control) were normal and were orally administered with $0.1 \mathrm{ml}$ of physiological saline. Group II mice (Negative control) were diabetic and were orally administered with 0.1 $\mathrm{ml}$ physiological saline. Group III mice (Positive control) were diabetic and were orally administered with Glibenclamide (reference drug) at a dose of 200 milligrams per kilogram body weight. Group IV, V, VI, VII, and VIII mice (Experimental groups) were diabetic and were orally given the plant extracts at doses of $25,48.4,93.5,180.9$, and $350 \mathrm{mg} / \mathrm{kg}$ body weight, respectively. This design was repeated but the treatment was administered intraperitoneally. The positive controls for the intraperitoneal route were administered with 0.12 units of insulin (1 $\mathrm{IU} / \mathrm{kg}$ body weight) in $0.1 \mathrm{ml}$ saline as the reference drug.

\section{Blood glucose, rate constant and half-life determination}

The tail of the mouse was sterilized with $10 \%$ alcohol then nipped to obtain the blood samples. This was done at the start of the experiment and then repeated after 2, 4, 6, 8, 10 and 24 hours. A drop of blood was then squeezed into a strip fixed in a Glucometer. Rate constant (k) was determined by plotting log concentration of blood sugar for the first four hours against time in hours. The plot gave the pseudo-first order rate constant $(\mathrm{k} / 2.303)$. The constant indicates the point where the straight line intersects the log concentration of blood sugar axis (this shows the original sugar concentration before administration of the drug) [13]. Calculation of the half-life was done by substituting for the rate constant in the formulae: $\mathrm{t}_{0.5}=0.693 / \mathrm{k}$. Half-life $\left(\mathrm{t}_{0.5}\right)$ is the time taken by the drug to reduce the plasma glucose by half [14]. The dose to be administered after certain duration was determined using exponential decay equation [15].

\section{Phytochemical determination}

Standard methods were used to screen the phytochemicals such as alkaloids, saponins, phenols, flavonoids and tannins present in Berberis holstii extracts [16,17].

\section{Statistical analysis of the collected data}

Statistical Package of Social Sciences (SPSS) software was used to analyze the collected data. Results were expressed as the Mean \pm standard deviation (SD) of the number of mice used per group. ANOVA and post-ANOVA were used in doing statistical analysis so as to make comparison of the normal control group means with those of diabetic group treated with saline, diabetic group treated with the conventionally used drugs, diabetic group treated with plant extracts at doses of 25, 48.4, 93.5, 180.9, and 350 milligram per kilogram body weight. Statistical significant was considered at $\mathrm{p} \leq 0.05$.

\section{Results}

Oral administration of aqueous extracts of Berberis holstii at the five doses given $(25,48.4,93.5,180.9$, and 350 milligrams per kilogram body weight) to mice showed blood glucose lowering effect from the $2^{\text {nd }}$ hour to the $8^{\text {th }}$ hour without depending on the dosage given. Percentage reductions in plasma glucose levels in animals by the extract of Berberis holstii at 25, 48.4, 93.5, 180.9, and 350 milligram per kilogram body weight at the $2^{\text {nd }}$ hour was $85.0 \%, 66.3 \%, 65.2 \%$, $73.7 \%$ and $77.5 \%$, respectively while the glibenclamide treated diabetic mice had their sugar level lowering to $78.1 \%$ within the same hour (Figure 1). The plant extract of Berberis holstii lowered the glucose levels in the blood but not to normal levels at this hour $\left({ }^{\mathrm{d}} \rho<0.05\right)$ (Table 1 ). The $93.5 \mathrm{mg} / \mathrm{kg}$ body weight dose, however, significantly decreased blood sugar levels as compared to the diabetic control $\left({ }^{\mathrm{a}} \rho<0.05\right)$ (Table 1). 
Citation: Kimani NL, Njangiru IK, Njagi ENM, Orinda GO (2017) Antidiabetic Activity of Administration of Aqueous Extract of Berberis holstii. J

\begin{tabular}{|c|c|c|c|c|c|c|c|}
\hline \multirow[b]{2}{*}{ Treatment } & \multirow[b]{2}{*}{ Route } & \multicolumn{6}{|c|}{ Levels of Glucose at different Times (mmol/L) } \\
\hline & & 0 hour & 2 hour & 4 hour & 6 hour & 8 hour & 24 hour \\
\hline \multirow[b]{2}{*}{ Control normal } & IP & $\underset{\text { ABDEFGH }}{5.20} \quad 0.03$ & $5.22 \pm 0.04^{\mathrm{ABDEH}}$ & $5.22 \pm 0.05^{\mathrm{A}}$ & $5.18 \pm 0.04^{\mathrm{A}}$ & $5.22 \pm 0.04^{\mathrm{A}}$ & $5.20 \pm 0.01^{A D E F G}$ \\
\hline & Oral & $\underset{\text { abefghi }}{5.22} \pm 0.04$ & $5.22 \pm 0.04$ ae & $5.20 \pm 0.05^{\mathrm{ae}}$ & $5.16 \pm 0.04^{\mathrm{a}}$ & $5.18 \pm 0.02^{\mathrm{a}}$ & $5.24 \pm 0.04^{\mathrm{ae}}$ \\
\hline \multirow[b]{2}{*}{ Negative control } & IP & $14.02 \pm 1.16^{\mathrm{C}}$ & $\begin{array}{ll}15.34 & \pm \\
1.22^{\mathrm{CBDEFG}} & \end{array}$ & $\begin{array}{ll}16.33 & \pm \\
1.31^{\mathrm{CBDEFGH}} & \end{array}$ & $\begin{array}{ll}18.06 & \pm \\
1.31^{\mathrm{CBDEFGH}} & \pm\end{array}$ & $\begin{array}{ll}19.34 & \pm \\
1.32^{\mathrm{CBDEFGH}} & \end{array}$ & $\begin{array}{l}22.94 \\
1.49 \mathrm{CBDEFGH}\end{array}$ \\
\hline & Oral & $15.64 \pm 1.71^{d}$ & $16.60 \pm 1.74^{\text {bei }}$ & $18.10 \pm 1.61$ & $19.28 \pm 1.79$ & $20.64 \pm 1.65$ & $23.16 \pm 1.81$ \\
\hline Positive control (insulin) & IP & $13.12 \pm 0.97^{C}$ & $6.62 \pm 0.16^{\mathrm{AH}}$ & $6.22 \pm 0.12^{\mathrm{A}}$ & $5.40 \pm 0.10^{\mathrm{A}}$ & $5.00 \pm 0.07^{\mathrm{A}}$ & $6.78 \pm 0.21^{\mathrm{A}}$ \\
\hline $\begin{array}{l}\text { Positive } \\
\text { (glibenclamide) }\end{array}$ & Oral & $13.4 \pm 0.86^{d}$ & $10.56 \pm 0.53^{d}$ & $7.20 \pm 0.37^{a}$ & $5.62 \pm 0.28^{a}$ & $4.96 \pm 0.08^{a}$ & $8.04 \pm 0.42^{\mathrm{a}}$ \\
\hline \multicolumn{8}{|c|}{ Extract dose ( $\mathrm{mg} / \mathrm{kg}$ body weight) } \\
\hline \multirow[b]{2}{*}{25} & IP & $14.22 \pm 1.03^{\mathrm{C}}$ & $10.34 \pm 0.79 \mathrm{C}^{\mathrm{A}^{*}}$ & $8.32 \pm 0.64^{\mathrm{A}^{*}}$ & $6.72 \pm 0.55^{A^{*}}$ & $5.70 \pm 0.25^{A^{*}}$ & $10.44 \pm 0.70^{C}$ \\
\hline & Oral & $15.32 \pm 1.72^{\mathrm{d}}$ & $13.20 \pm 1.98^{\mathrm{d}^{*}}$ & $10.80 \pm 1.75^{\mathrm{da}^{*}}$ & $7.96 \pm 1.33^{\mathrm{a}^{*}}$ & $6.44 \pm 0.68^{\mathrm{a}^{*}}$ & $12.30 \pm 1.61^{\mathrm{da}}$ \\
\hline \multirow[b]{2}{*}{48.4} & IP & $15.42 \pm 1.33 \mathrm{C}$ & $9.78 \pm 1.17^{\mathrm{CA}}$ & $6.92 \pm 0.70^{A}$ & $5.56 \pm 0.28^{\mathrm{A}}$ & $4.86 \pm 0.18^{A}$ & $9.34 \pm 0.90^{C A}$ \\
\hline & Oral & $15.60 \pm 2.28 \mathrm{~d}$ & $10.34 \pm 1.39^{d}$ & $6.80 \pm 0.61^{a}$ & $5.58 \pm 0.48^{\mathrm{a}}$ & $4.68 \pm 0.27^{\mathrm{a}}$ & $10.12 \pm 1.07^{a}$ \\
\hline \multirow[b]{2}{*}{93.5} & IP & $14.46 \pm 0.82 \mathrm{C}$ & $8.32 \pm 0.71^{\mathrm{A}}$ & $6.06 \pm 0.42^{A}$ & $4.96 \pm 0.09^{A}$ & $4.42 \pm 0.15^{A}$ & $9.34 \pm 0.49^{C A}$ \\
\hline & Oral & $14.32 \pm 1.38 \mathrm{~d}$ & $9.34 \pm 1.44^{a}$ & $6.86 \pm 0.94^{a}$ & $5.58 \pm 0.56^{a}$ & $4.86 \pm 0.46^{a}$ & $10.32 \pm 0.87^{a}$ \\
\hline \multirow{4}{*}{180.9} & IP & $13.70 \pm 1.78 \mathrm{C}$ & $9.26 \pm 0.76^{A}$ & $7.36 \pm 0.62^{A}$ & $5.48 \pm 0.50^{A}$ & $4.72 \pm 0.40^{A}$ & $9.48 \pm 0.86^{\mathrm{CA}}$ \\
\hline & Oral & $14.22 \pm 1.63 d$ & $10.48 \pm 1.20^{d}$ & $7.90 \pm 0.76^{a}$ & $5.72 \pm 0.55^{a}$ & $5.5 . \pm 0.66^{a}$ & $9.90 \pm 0.90^{a}$ \\
\hline & IP & $15.50 \pm 1.37 \mathrm{C}$ & $11.36 \pm 1.41^{\mathrm{CB}}$ & $8.30 \pm 0.66^{A}$ & $6.74 \pm 0.39^{A}$ & $5.14 \pm 0.12^{\mathrm{A}}$ & $7.14 \pm 0.25^{A}$ \\
\hline & Oral & $16.36 \pm 1.71 \mathrm{~d}$ & $12.68 \pm 1.70^{\mathrm{d}}$ & $9.78 \pm 1.45^{\mathrm{a}}$ & $7.66 \pm 0.84^{a}$ & $5.54 \pm 0.47^{\mathrm{a}}$ & $7.24 \pm 0.96^{\mathrm{a}}$ \\
\hline \multicolumn{8}{|c|}{ 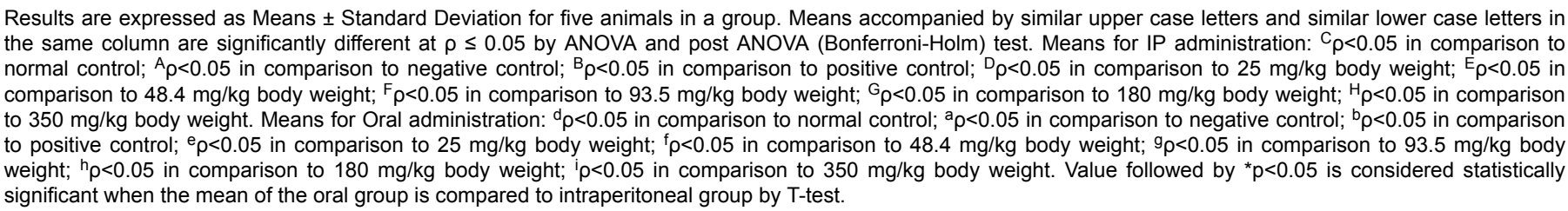 } \\
\hline
\end{tabular}

Table 1: Effects of administration of five therapeutic doses of Berberis holstii extract at different times on blood sugar levels. 


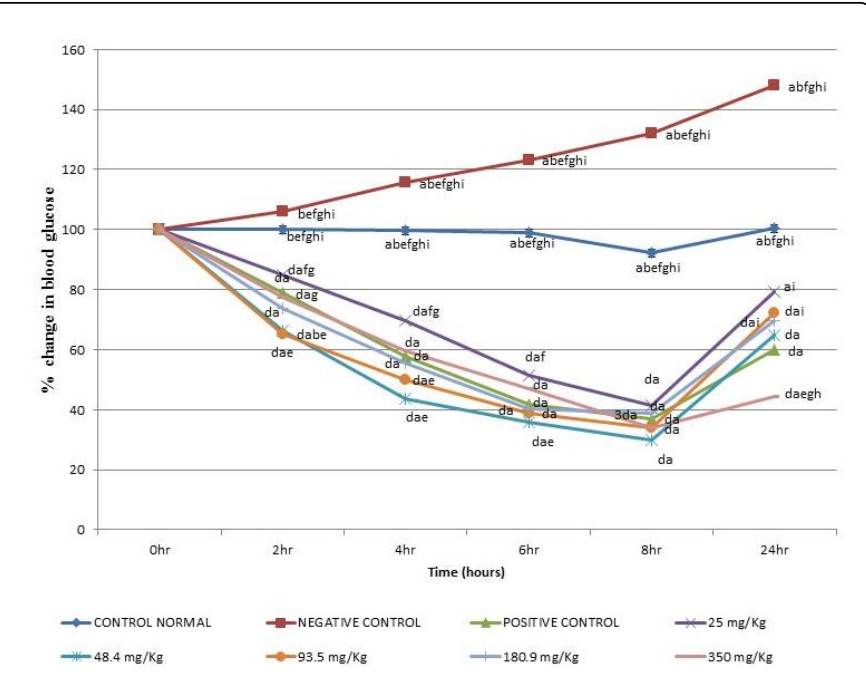

Figure 1: Percentage reduction in blood glucose levels at varying times after oral administration of the aqueous extracts of Berberis holstii in alloxan-induced diabetic male mice. Values are expressed as $\%$ means \pm SEM for five animals for each time point. ${ }^{\mathrm{D}} \rho<0.05$ in comparison to normal control; ${ }^{a} \rho<0.05$ in comparison to negative control; ${ }^{\mathrm{b}} \rho<0.05$ in comparison to positive control; ${ }^{\mathrm{e}} \rho<0.05$ in comparison to $25 \mathrm{mg} / \mathrm{kg}$ body weight; $\mathrm{f} \rho<0.05$ in comparison to $48.4 \mathrm{mg} / \mathrm{kg}$ body weight; $\mathrm{g} \rho<0.05$ in comparison to $93.5 \mathrm{mg} / \mathrm{kg}$ body weight; ${ }^{h} \rho<0.05$ in comparison to $180 \mathrm{mg} / \mathrm{kg}$ body weight; ${ }^{\mathrm{i}} \rho<0.05$ in comparison to $350 \mathrm{mg} / \mathrm{kg}$ body weight.

Glucose-lowering effect was also observed at the $4^{\text {th }}$ hour, the percentage reduction of blood glucose was $69.6 \%$, 43.6\%, $49.9 \% 55.6 \%$ and $59.8 \%$, respectively, relative to glibenclamide treated diabetic mice which showed $57.7 \%$ lowering effect within the same hour. In the $6^{\text {th }}$ hour, the extract lowered the plasma glucose levels by $51.3 \%, 35.8 \%$, $39.0 \%, 40.2 \%$ and $46.8 \%$, respectively, compared to diabetic mice treated with glibenclamide whose blood glucose levels decreased to $41.9 \%$. The extract decreased the plasma sugar levels to normal $\left({ }^{d} \rho>0.05\right)$. At this hour the extract was effective as glibenclamide in lowering blood sugar levels $\left({ }^{b} \rho<0.05\right)$ especially by the $180.9 \mathrm{mg} / \mathrm{kg}$ body weight dose range. The same trend was observed during the $8^{\text {th }}$ hour where the five dose levels lowered blood glucose to levels lower than those of glibenclamide (37.0\%). The percentage blood glucose reductions were $41.5 \%, 30 \%, 33.9 \%, 38.7 \%$ and $33.9 \%$, respectively (Figure 1).

Intraperitoneal administration of aqueous extracts of Berberis holstii at 25,48.4, 93.5, 180.9, and 350 milligrams per kilogram body weight to mice lowered blood sugar level significantly as from the $2^{\text {nd }}$ hour to the $8^{\text {th }}$ hour in a manner not dependent on the dose. Percentage reductions in plasma sugar levels in diabetic mice by the extract of Berberis holstii at the five dosages during the 2nd hour was $72.7 \%, 63.4 \%, 57.5 \%, 67.6 \%$ and $73.2 \%$, respectively, while insulin administered diabetic mice showed blood sugar lowering to $50.5 \%$ within the same hour (Figure 2). At this hour the Berberis holstii extract lowered the blood sugar levels but not to normal $\left({ }^{\mathrm{C}} \rho<0.05\right)$ (Table 1). The doses, however, significantly lowered blood glucose levels with respect to the diabetic control $\left({ }^{\mathrm{A}} \rho<0.05\right)$ (Table 1).

The percentage blood sugar lowering effect observed at the $4^{\text {th }}$ hour was; $58.5 \%, 44.9 \%, 41.9 \% 53.7 \%$ and $53.6 \%$, respectively, with respect to insulin-treated diabetic mice whose blood sugar levels lowered to $47.4 \%$ by the same hour. In the $6^{\text {th }}$ hour, the extract decreased blood sugar levels by $47.3 \%, 36.4 \%, 34.3 \%, 40.0 \%$ and $43.5 \%$, respectively, in comparison to diabetic mice treated with insulin whose blood glucose levels decreased to $41.2 \%$. The extract lowered blood glucose levels to normal $\left({ }^{C} \rho>0.05\right)$. At this hour the blood sugar lowering effect of the extract is comparable to insulin $\left({ }^{\mathrm{B}} \rho<0.05\right)$ especially by the 180.9 $\mathrm{mg} / \mathrm{kg}$ body weight dose. The same trend was observed during the $8^{\text {th }}$ hour where the five dose levels lowered blood glucose levels lower than even insulin which lowered to $38.1 \%$. The percentage blood glucose reductions were $40.1 \%, 31.5 \%, 30.6 \%, 34.5 \%$ and $33.2 \%$, respectively (Figure 2).

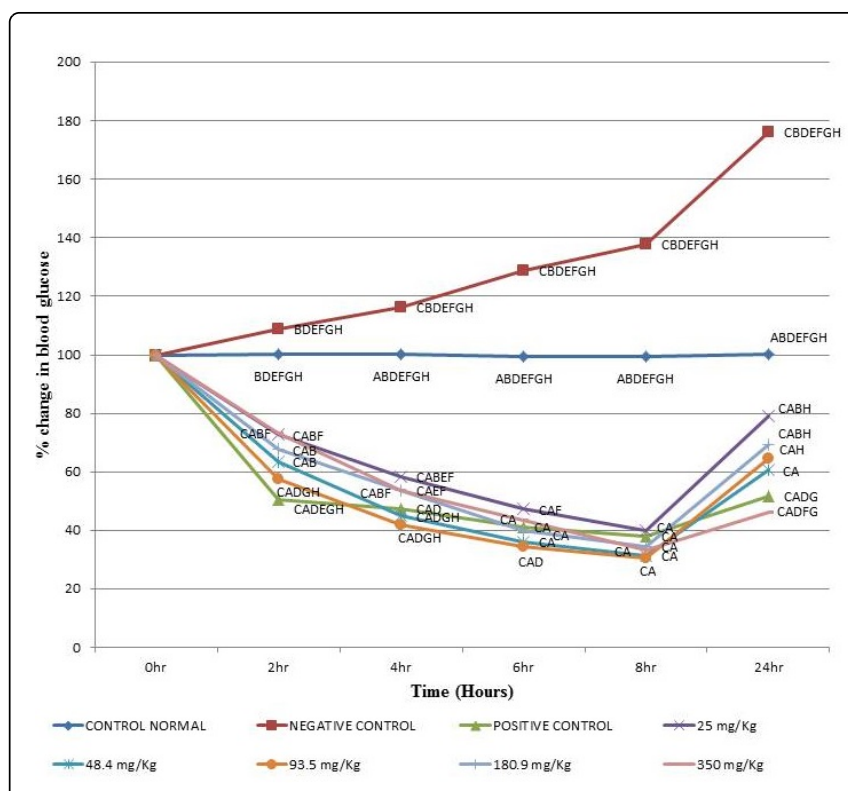

Figure 2: Percentage reduction in blood glucose levels at varying times after intraperitoneal administration of the aqueous extracts of Berberis holstii in alloxan-induced diabetic male mice. Values are expressed as \% means \pm SEM for five animals for each time point. $\mathrm{C} \rho<0.05$ in comparison to normal control; $\mathrm{A} \rho<0.05$ in comparison to negative control; $\mathrm{B} \rho<0.05$ in comparison to positive control; $\mathrm{D} \rho<0.05$ in comparison to $25 \mathrm{mg} / \mathrm{kg}$ body weight; $\mathrm{E} \rho<0.05$ in comparison to $48.4 \mathrm{mg} / \mathrm{kg}$ body weight; $\mathrm{F} \rho<0.05$ in comparison to $93.5 \mathrm{mg} / \mathrm{kg}$ body weight; $\mathrm{G} \rho<0.05$ in comparison to $180 \mathrm{mg} / \mathrm{kg}$ body weight; $\mathrm{H} \rho<0.05$ in comparison to $350 \mathrm{mg} / \mathrm{kg}$ body weight.

Table 2 shows the pharmacokinetics of the blood sugar lowering effect for the first 4 hours of the aqueous root extracts of $B$. holstii. As indicated by the results the rate constant at pseudo-first order level for the orally administered doses of the aqueous root extracts of $B$. holstii at $25 \mathrm{mg} / \mathrm{kg}$ and $48.4 \mathrm{mg} / \mathrm{kg}$ was 0.1813 and 0.4152 and their accompanying half-life's were 3.82 and 1.67 while those of the other three doses were similar. The half-life of $25 \mathrm{mg} / \mathrm{kg}$ dose was higher than that of glibenclamide but those of the rest doses were lower. Rate constant at pseudo-first order level for the intraperitoneally administered doses of the aqueous root extracts of $B$. holstii at 25 $\mathrm{mg} / \mathrm{kg}, 48.4 \mathrm{mg} / \mathrm{kg}$ and $93.5 \mathrm{mg} / \mathrm{kg}$ were $0.268,0.4006$ and 0.4348 and half-lifes associated with them were $2.59,1.73$ and 1.59 while those of the other two doses were similar. The half-lifes of $48.4 \mathrm{mg} / \mathrm{kg}$ and 93.5 were lower than that of insulin while those of the other doses of extract of $B$. holstii were higher. A range of rate constant per hour of 0.1813 to 
Page 5 of 6

0.4152 was observed for the aqueous extract orally administered at five dose levels.

\begin{tabular}{|l|l|l|l|}
\hline Drug & Route & Rate constant (per hour) & Half-life (hours) \\
\hline Insulin & IP & 0.3732 & 1.86 \\
\hline Glibenclamide & Oral & 0.3106 & 2.23 \\
\hline \multirow{2}{*}{ Extract (mg/kg body weight) } & \multicolumn{2}{|l|}{} \\
\hline \multirow{2}{*}{25} & IP & 0.268 & 2.59 \\
\hline \multirow{2}{*}{48.4} & Oral & 0.1813 & 3.82 \\
\hline \multirow{2}{*}{93.4} & IP & 0.4006 & 1.73 \\
\cline { 2 - 4 } & Oral & 0.4152 & 1.67 \\
\hline \multirow{2}{*}{180.9} & IP & 0.4348 & 1.59 \\
\cline { 2 - 5 } & Oral & 0.368 & 1.88 \\
\hline \multirow{2}{*}{ Results are expressed as } & IP & 0.3107 & 2.23 \\
\cline { 2 - 5 } & Oral & 0.368 & 1.88 \\
\cline { 2 - 4 } & IP & 0.3123 & 2.22 \\
\hline
\end{tabular}

Results are expressed as Means of five mice for each time point

Table 2: Pharmacokinetics of the hypoglycemic effect for the first 4 hours of the five doses of the extracts of B. holstii.

However, the range of the half-lifes of the five dose levels was between 3.82 to 1.67 hours respectively. The rate constants for aqueous extracts administered intraperitoneally at the five dose level ranged from 0.268 to 0.4348 in an hour while the half-lifes range was from 2.59 to 1.73 hours, respectively. Insulin and glibenclamide rate constant were 0.3732 and 0.3106 respectively and their accompanying half-lifes 1.86 and 2.23 hour in the same order.

\section{Quantitative determination of the phytochemicals present in aqueous root extracts of Berberis holstii}

The screening of phytochemicals present the aqueous root extracts of Berberis holstii indicated the presence of alkaloids, phenols, tannins, saponins and flavonoids as shown in Table 3.

\begin{tabular}{|l|l|l|l|l|l|}
\hline \multirow{2}{*}{ Sample } & \multicolumn{4}{l}{ Phytochemical Content $(\mathbf{m g} / \mathbf{g})$} & \multicolumn{2}{l|}{} \\
\cline { 2 - 7 } & $\begin{array}{l}\text { Total } \\
\text { Phenols }\end{array}$ & Tannins & $\begin{array}{l}\text { Flavonoid } \\
\text { s }\end{array}$ & Saponins & Alkaloids \\
\hline $\begin{array}{l}\text { Berberis } \\
\text { holstii }\end{array}$ & $\begin{array}{l}3.61 \quad \pm \\
0.50\end{array}$ & $0.80 \pm 0.12$ & $2.15 \pm 0.04$ & $\begin{array}{l}83.38 \\
1.94\end{array}$ & $\begin{array}{l}17.27 \\
0.94\end{array}$ \\
\hline
\end{tabular}

Quantities are expressed as Mean \pm Standard Deviation (SD) of three determinations. The quantities of phytochemicals were expressed as milligram per gram of dry extract

Table 3: Quantitative determinations of the phytochemicals present in the extract Berberis holstii.

\section{Discussion}

The alloxan-induced diabetic mice had much higher blood sugar level compared to normal control group. Oral and intraperitoneal administration of the aqueous extract of the Berberis holstii exhibited decrease in blood sugar level at 25, 48.4, 93.5, 180 and 350 milligram per kilogram body weight. The hypoglycemic activity the aqueous root extracts of Berberis holstii confirmed it has antidiabetic activity.

The blood sugar lowering effect could be associated to alkaloids present [18]. Alkaloid fraction from $C$. decidua has been shown to have antidiabetic activity in mice [19]. Berberine and tetrandine alkaloids have been shown to have the antioxidant effect which is responsible for different biological activities found in the plant like antidiabetic activity. The alkaloids l-ephedrine of Ephedra distachya herbs has demonstrated the antidiabetic effect in diabetic mice as a result of restoration and regeneration of atrophied pancreatic islets that induces the secretion of insulin [20].

Saponins were found to be present in aqueous root extract of Berberis holstii. Saponins have been demonstrated to have antidiabetic effect. For example, saponins in ginseng have been demonstrated to lower blood glucose in alloxan-induced, diabetic, and normal mice [21]. Saponin isolated from Momordica charantia decreased blood sugar levels and increased insulin production and glycogen production in alloxan treated diabetic mice [22]. As reported by [23] saponins were demonstrated to decrease blood sugar levels in elderly diabetic patients. Saponins from the Entada phaseoloides seeds significantly decreased fasted blood sugar and correct hyperglycemia associated oxidative stress in type 2 diabetic rats [24].

Berberis holstii aqueous extract contains tannins which are known to have the antidiabetic activity. Acacia nilotica was demonstrated to contain $50 \%$ tannins that exhibited hypoglycemic activity in diabetic subjects. All forms of tannins in clinical terms may participate in the management of blood sugar level. Tannin has been demonstrated to stimulate the receptor cells to utilize carbohydrate [25].

The antidiabetic activity observed in Berberis holstii could have been due to the presence of flavonoids. Flavonoids such as polyhydroxylated flavonol, myricetin, have insulinomimetic properties and stimulate lipogenesis and transport of glucose in the adipocytes, hence decreasing blood sugar [26]. It has also been demonstrated that flavonoid fraction from Pterocarpus marsupiu could cause pancreatic beta-cell regulation [27]. Glycosides flavonoids of Psidium guajava such as strictinin, isostrictinin and pedunculagin have been used in the management of diabetes due to improved sensitivity of insulin [28].

\section{Conclusion}

The aqueous root extracts of Berberis holstii has hypoglycemic activity. Both the oral and intraperitoneal routes were effective in decreasing the blood sugar levels. The hypoglycemic activity of the studied plant may be associated with a host of phytochemical constituents present. The study, therefore, recommends the folkloric use of Berberis holstii and established their efficacy result that can guide proper use of the plant in the management of diabetes mellitus. The study, however, recommends undertaking of further research on this plant to establish the mechanism of the hypoglycemic activity to explore possibilities of developing a drug that can function by a similar mode of action as the plant extract. 
Citation: Kimani NL, Njangiru IK, Njagi ENM, Orinda GO (2017) Antidiabetic Activity of Administration of Aqueous Extract of Berberis holstii. J

Page 6 of 6

\section{References}

1. Piero NM, Kimuni NS, Ngeranwa NJ, Orinda OG, Njagi MJ, et al. (2015) Antidiabetic and Safety of Lantana rhodesiensis in Alloxan Induced Diabetic Rats. J Develop Drugs 4: 129.

2. Edwin E, Sheeja E, Gupta VB, Jain DC (2006) Fight Diabetes the herbal way. Express Pharma review 1:41-42.

3. American Diabetes Association (2012) Diagnosis and Classification of Diabetes Mellitus. Diabetes care 35: S64-S71

4. World Health Organization (2015) Diabetes Fact Sheet NO.312.

5. Piero MN, Njagi JM, Kibiti CM, Ngeranwa JJN, Njagi ENM (2012) Metabolic Complications of Diabetes Mellitus: A Review. South As J Biol Sci 2: 37-49.

6. Kerner W, Brückel J. German Diabetes Association ( 2014) Definition, classification and diagnosis of diabetes mellitus. Exp Clin Endocrinol Diabetes 122: 384-386.

7. Murugi NJ, Piero NM, Mwiti KC, Ngeranwa JJN, Njagi ENM, et al. (2012) Hypoglycemic effects of Caesalpinia volkensii on alloxan-induced diabetic mice.

8. Rao MU, Sreenivasulu M, Chengaiah B, Reddy KJ, Chetty CM (2010) Herbal Medicines for Diabetes Mellitus: A Review. Int J Pharmtech Res 2: 1883-1892.

9. Scicchitano P, Cameli M, Maiello M, Modesti PA, Muiesan ML, et al. (2014) Nutraceuticals and dyslipidaemia: Beyond the common therapeutics. J Func Foods 6: 11-32.

10. Mahmood A, Mahmood A, Qureshi RA (2012) Antimicrobial activities of three species of family mimosaceae. Pak J Pharm Sci 25: 203-206.

11. Piero NM, Njagi MJ, Kibiti MC, Ngeranwa JJN, Njagi NM, et al. (2012) Herbal management of diabetes mellitus: A rapidly expanding research avenue.

12. Pandey A, Tripathi P, Pandey R, Srivatava R, Goswami S (2011) Alternative therapies useful in the management of diabetes: A systematic review. J Pharm Bioallied Sci 3: 504-512.

13. Lin VW, Cardenas DD (2003) Spinal cord medicine. Demos Medical Publishing LLC pp 251.

14. John A (1989) 20th Century Words. Cambridge University Press.

15. Evans WE, Schentag JJ, Jusko WJ, Harrison H (1992) In: Evans WE, JJ Schentag (eds) Applied Pharmacokinetics: Principles of Therapeutic Drug Monitoring (3rdedn) Vancouver: Applied Therapeutics.
16. Hosseinzadeh H, Younesi HM (2002) Antinociceptive and antiinflammatory effects of Crocus sativus L. stigma and petal extracts in mice. BMC Pharmacol 2: 7.

17. Houghton PJ, Raman A (1998) Laboratory Handbook for the Fractionation of Natural extracts. Chapman and Hall 154-187.

18. Tiong SH, Looi CY, Hazni H, Arya A, Paydar M, et al. (2013) Antidiabetic and antioxidant properties of alkaloids from Catharanthus roseus ( L.) G. Don. Molecules 18: 9770-9784.

19. Jadhav R, Puchchakayala G (2012) Hypoglycemic and Antidiabetic Activity of Flavonoids: Boswellic Acid, Ellagic Acid, Quercetin, Rutin on Streptozotocin- Nicotinamide Induced Type 2 Diabetic Rats. Int J Pharm Pharmaceu Sci 4.

20. Elliot M, Chithan K, Theoharis CT (2000) The effects of plant flavanoids onm mammalian cells: Implications for inflammation, heart disease and cancer. Pharmacol Rev 52: 673-751.

21. Kimura M, Suzuki J (1985) The pharmacological role of ginseng in the blend effect of traditional Chinese medicines in hyperglycemia. Advances of Chinese Medicinal Materials Research, World Scientific, Singapore.

22. Han C, Hui Q, Wang Y ( 2008) Hypoglycaemic activity of saponin fraction extracted from Momordica charantia in PEG/salt aqueous twophase systems. Nat Prod Res 22: 1112-1119.

23. Chen KJ, Zhang WP ( 1987) Advances on antiageing herbal medicines in China. Abstracts of Chinese Medicine 1: 309-330.

24. Zheng T, Shu G, Yang Z, Mo S, Zhao Y ( 2012) Antidiabetic effect of total saponins from Entada phaseoloides ( L.) Merr. in type 2 diabetic rats. J Ethnopharmacol 139: 814-821.

25. Kumari M, Jain S, Dave R (2014) Babul (Acacia nilotica), A potential source of tannin and its suitability in management of type II diabetes. Nutrition \& Food Science 2: 122-124

26. Modak M, Dixit P, Londhe J, Ghaskadbi S, Devasagayam TP (2007) Indian herbs and herbal drugs used for the treatment of diabetes. J Clin Biochem Nutr 40: 163-173.

27. Li F, Li Q, GAO D, Peng Y (2009) The optimal extraction parameters and anti-diabetic activity of flavonoids from Ipomoea batatas leaf. Afr J Tradit Complement Altern Med 2: 195-202.

28. Shukla S, Mehta A, Mehta P, Bajpai VK (2012) Antioxidant ability and total phenolic content of aqueous leaf extract of Stevia rebaudiana Bert. Exp Toxicol Pathol 64: 807-811. 